\title{
A FRAMEWORK FOR ASSESSING THE ROLE OF KARST CONDUIT MORPHOLOGY, HYDROLOGY, AND EVOLUTION IN THE TRANSPORT AND STORAGE OF CARBON AND ASSOCIATED SEDIMENTS
}

\author{
OSNOVA ZA OCENJEVANJE VLOGE MORFOLOGIJE, \\ HIDROLOGIJE IN RAZVOJA KRAŠKIH KANALOV PRI PRENOSU \\ IN SKLADIŠČENJU OGLJIKA IN SORODNIH SEDIMENTOV
}

\author{
George VENI ${ }^{1}$
}

\begin{abstract}
UDC 551.444:546.26

George Veni: A framework for assessing the role of karst conduit morphology, hydrology, and evolution in the transport and storage of carbon and associated sediments

Karst aquifers and conduits form by dissolution of carbonate minerals and the slow release of inorganic carbon to the surface environment. As conduits evolve in size, morphology, and position within the aquifer, their function and capacity change relative to the storage and transport of inorganic and organic carbon as sediment. Conduits serve mostly as transport mechanisms in relation to sediments. Quantified data are sparse, but for conduits to function effectively there must be at least equilibrium in the amount of sediment entering and exiting the aquifer. If sediment discharge exceeds input, little sediment will remain underground. When natural declines in base level cease removing sediments and only deposit calcite speleothems, these materials are stored until the rock mass is denuded. While sediment storage is mostly transient in hydrologically active conduits, relative differences occur. Aquifers with conduits developed at multiple levels or as floodwater mazes store proportionately greater volumes of sediment. Hypogenic systems should store greater volumes of sediment than epigenic aquifers because they mostly discharge a dissolved load as opposed to both dissolved and suspended clastic loads. However, some hypogenic aquifers are diffusely recharged and receive and store little sediment from the surface. The global volume of sediment and organic carbon stored in karst aquifers is estimated in this study to be on the order of $2 \times 10^{4} \mathrm{~km}^{3}$ and $2 \times 10^{2} \mathrm{~km}^{3}$, respectively. The amount of organic carbon stored in paleokarst is not estimated, but available data indicate it is substantially greater than that stored in modern karst aquifers. Development of such data may suggest that paleokarst petroleum reservoirs might serve as efficient carbon sinks for global carbon sequestration. Hydrocarbon-depleted paleokarst reservoirs should provide substantially more storage per injection well than sequestration in non-paleokarstic rocks.

Keywords: Sediment, carbon, paleokarst, conduit morphology, karst hydrology, sequestration.
\end{abstract}

Izvleček

UDK 551.444:546.26

George Veni: Osnova za ocenjevanje vloge morfologije, hidro-

logije in razvoja kraških kanalov pri prenosu in skladiščenju ogljika in sorodnih sedimentov

Kraški vodonosniki in kanali nastajajo $\mathrm{z}$ raztapljanjem karbonatnih mineralov in počasnim sproščanjem anorganskega ogljika. Z razvojem morfologije, velikosti in položajem znotraj vodonosnika, se njihova funkcija in zmogljivost skladiščenja ter prenosa anorganskega in organskega ogljika spremenita. Kanali sedimentom služijo predvsem kot transportni mehanizmi. Merjeni podatki so redki, vendar je za učinkovito delovanje kanalov potrebno vsaj ravnotežje med količino sedimentov, ki vstopijo in izstopijo iz vodonosnika. Ko količina sedimentov preseže vstopne vrednosti, bo nekaj sedimenta ostalo v podzemlju. Ko naravno upadanje doseže odstranitev sedimentov in prihaja le do odlaganja sige, se ta material uskladišči vse do popolne denudacije kamninske mase. Skladiščenje sedimenta je $\mathrm{v}$ hidrološko aktivnih kanalih večinoma prehodno, vendar prihaja do relativnih razlik $\mathrm{v}$ različnih vodonosnikih. Vodonosniki s kanali, razvitimi v več nivojih ali kot labirinti poplavnih voda, skladiščijo sorazmerno večje količine sedimentov. Hipogeni sistemi hranijo večje količine usedlin kot epigeni vodonosniki, saj večinoma prevajajo raztopljeni material in ne toliko kombinacije raztopljenih in suspendiranih klastičnih usedlin. Poleg tega se hipogeni vodonosniki večinoma napajajo s padavinami in tako prejmejo in skladiščijo le malo sedimentov s površine. Količina sedimentov in organskega ogljika shranjenega $\mathrm{v}$ kraških vodonosnikih na globalni ravni je $\mathrm{v}$ tej študiji ocenjena na $2 \times 10^{4} \mathrm{~km}^{3}$ and $2 \times 10^{2} \mathrm{~km}^{3}$. Količina organskega ogljika shranjenega v paleokrasu ni ocenjena, vendar razpoložljivi podatki kažejo, da je bistveno večja od količine, shranjene v aktivnih kraških vodonosnikih. Ureditev teh podatkov lahko nakaže, da bi zaloge nafte v paleokrasu lahko služile kot učinkoviti ponori ogljika za globalno skladiščenja ogljika. Paleokraške zaloge z manjšo vsebnostjo ogljikovodikov morajo zagotoviti bistveno več skladiščenja kot je to značilno za nepaleokraške kamnine.

Ključne besede: sediment, ogljik, paleokras, morfologija kanalov, kraška hidrologija, skladiščenje.

\footnotetext{
${ }^{1}$ National Cave and Karst Research Institute, 400-1 Cascades Avenue, Carlsbad, New Mexico 88220-6215, USA,

e-mail: gveni@nckri.org
}

Received/Prejeto: 3.2.2013 


\section{INTRODUCTION}

Caves are commonly thought of as dirty places, so it is ironic that cave sediments have seen relatively little study as compared to topics such as cave hydrology, morphology, and mineralogy. Reviews by Ford (2001), Gillieson (2004), Sasowsky (2004), and Springer (2005) nicely summarize how sediments accumulate in karstic caves as passages dissolutionally and mechanically enlarge, leaving collapsed rock and insoluble materials behind (autochthonous sediments). They further explain how as cave entrances and sinkholes enlarge, increasingly greater amounts of sediment move underground through the action of water, wind, and animals (allochthonous sediments). Most detailed studies focus on the mechanism of cave sedimentation, generally in regard to a specific cave or karst area (e.g. Bottrell et al. 1999), while others investigate sediment stratigraphy or content (typically bone or mineral) to interpret modern to past hydrologies, contaminant transport, paleoclimate, and potential economic resources. Sasowsky and Mylroie (2004) provide several examples.

Cave sediment generally includes inorganic carbon, often in the form of speleothems, and organic carbon, often plant and animal detritus. The study of carbon in cave sediments is a largely uninvestigated topic but one which is gaining attention. The purpose of this paper is to use the published information available on cave car- bon to establish a conceptual framework on how organic and inorganic carbon enters, is stored, in some cases produced in, and ultimately returned to the surface from karst caves and aquifers. Testing and refinement of this framework by future authors is encouraged.

This paper focuses on the role of conduit morphology, aquifer hydrology, and changes in sediment and carbon movement and distribution, as individual conduits and aquifers evolve. One section estimates the critically important total volume of sediment and carbon stored in karst conduits; paleokarst is considered separately. For the purposes of this paper, sediment within the aquifer is considered fluvial in the sense of how most of it is transported and deposited; sediment transport by wind and animals, while at times locally significant, rarely extends far into the aquifer system. "Conduit" is generally used rather than "cave" to include caves as well as voids too small for human access but formed by turbulent groundwater flow and which collectively play significant roles relative to sediment and carbon. Similarly, "sediment" is used to address the total mass of material; its application to carbon is implied. "Carbon" is used when specificity is required. Chemolithoautotrophic microbes potentially produce a major source of organic carbon in karst systems but are not considered in this paper.

\section{CONDUIT MORPHOLOGY AND HYDROLOGY}

One of the defining characteristics of a karst conduit is its ability to transmit turbulent groundwater flow and hence sediment. A conduit's tendency to deposit, erode, or transport sediment depends on two primary factors: conduit morphology and conduit and aquifer hydrology. See Veni (2005) for a summary of conduit types and origins.

Certain basic principles of sediment movement and distribution relative to conduit morphology and hydrology must be acknowledged. The potential for sediment transport, as opposed to deposition, increases with:

1) conduit slope;

2) hydraulic gradient;

3) smoother conduit cross sections;

4) frequency of flood events;

5) magnitude of flood events;

6) position with respect to the water table; and

7) decreases in conduit width that focus erosion on passage floors.
All of these factors assume at least intermittently turbulent groundwater flow through the conduit to carry sediment. Position with respect to the water table is the least reliable predictor of sediment transport; conduits high in the vadose zone have the greatest competence to erode sediments while those closer to the water table are more likely to carry converged groundwater flow with a far greater capacity to move sediment. Herman et al. (2012) provide a detailed review of factors affecting sediment transport through karst aquifers.

Based on the above principles, rough predictions can be made about gross sediment distribution throughout a particular cave or karst aquifer if some of those parameters are known. The availability of sediment on the surface is generally not a major factor in those principles. While it has an effect on short-term deposition and erosion, the long-term function of the conduit will be determined by those principles; differences in sediment input will mostly affect the degree of how sediment is trans- 
ported or deposited, not the general principles affecting transport and deposition.

Throughout the history of a conduit, its primary function is to transport water and to a generally lesser degree, sediment, in, through, and out of the karst aquifer; storage is a relatively minor function. Data which quantify the volume of sediment stored in a karst aquifer are sparse, relative to the sediment that flushes through it, but Worthington (1984) provides an instructive example. Analogous information is also available for comparison and to support the point. A useful study is that of Worthington et al. (2000) who found in studying four distinct types of unconfined karst aquifers that the volume of water stored in the conduits ranged from 0.05 $2.8 \%$ while $94-99.7 \%$ of the groundwater transported through the aquifer over time moved through the conduits. When considering that the same water carries sediment and dissolved solids, even though the energy and stresses needed to move sediment are greater than just moving water, it is reasonable to assume that only a small percentage of that sediment is stored in the hydrologically active part of the aquifer at a given time, while a vastly greater volume is washed through. Groves and Meiman (2001) give an example of a cave system that is discharging stored sediments and limestone eroded from cave walls in a far greater volume than the sediment which enters that aquifer.

For most of their histories, karst aquifers must function close to equilibrium or at a sediment deficit relative to the amount of sediment entering and exiting; how this equilibrium relates to the increase in total stored sediment as conduits enlarge is discussed later. Prolonged sediment surplus will result in the filling of the conduits and a non- or poorly-functional aquifer; Herman et al. (2012) offer an equation that quantifies this behavior. Typically, a cave stream will erode or deposit sediment until equilibrium is reached relative to the volume, gradient, grain size, and other conditions of the stream. Major episodes of erosion or deposition may take millennia to recover, or may recover within the time frame a single storm event. For example, Van Gundy and White (2009) describe a flood dislodging $1,800 \mathrm{~m}^{3}$ of soil from a sinkhole into a cave. After the flood, no measureable accumulation of sediment was found inside, which considering the conditions of the cave strongly suggest that most was transported through. Bosch and White (2004) offer an equation for measuring sediment flux through a karst groundwater drainage basin.

Sediment storage is mostly transient in hydrologically active conduits, but relative differences occur due to differences in conduit morphology, hydrology, and origin. Palmer (1991) identified 15 major types of conduit patterns based on a karst aquifer's dominant poros- ity and type of recharge. In general, mazes and multitiered caves, no matter their origin and in proportion to their active groundwater flow, have the potential to store greater volumes of sediment than other types of caves. These types of caves have a high proportion of passage volume for sediment storage relative to the volume of their active or seasonally active streams. In both cases, flood waters rise into higher level passages and mazes where sediment is deposited. Sedimentation is especially enhanced in maze caves where the injected flood water becomes ponded or nearly ponded in the conduits, allowing sediment to settle with little potential for removal; high passages that can sustain significant currents provide relatively less opportunity for sedimentation.

Palmer (1991) recognized three main types of recharge: karst depressions, diffuse, and hypogenic. Gravity-drained epigenic aquifers with either depression-focused or diffuse recharge discharge dissolved, suspended, and bedload sediments. In principle, hypogenic conduits should proportionally store more sediment as discussed below at the end of this section.

Palmer's (1991) classification system is also useful in assessing the type of sediment in each type of aquifer. Those recharged by sinkholes and other focused sources have the greatest sediment diversity, containing allochthonous and autochthonous sediments with the allochthonous sediments potentially including non-carbonates/non-evaporites washed in from adjacent rocks. They also contain the greatest percentage of organic carbon from soils, plants, and animals carried into the conduits by water, wind, or gravity.

Diffusely recharged karst aquifers contain few allochthonous clastic sediments. Organic carbon is primarily limited to tree roots that may penetrate conduits, and organic particles and dissolved carbon moving down fractures (e.g. Toth 1998). However, diffusely recharged aquifers that discharge near valley floors may contain substantial organic carbon deposited by backflooding of surface streams into the conduits. Although not a diffusely recharged karst aquifer, Mammoth Cave, USA, provides an excellent example of extensive sediment transport that resulted from backflooding. Hendrickson (1961) and Collier and Flint (1964) found clay and silt deposited up to $6 \mathrm{~cm}$ thick and at least $2 \mathrm{~km}$ into the cave.

Hypogenic aquifers discharge rising water under pressure, with gravity holding much of the suspended load and bedload in the aquifer, consequently resulting in a relatively greater accumulation of insoluble sediment with the soluble fraction removed in the dissolved load. Because most conduits in hypogenic aquifers are deep below the water table and not readily observable, this proportionately greater sediment accumulation is 
often not apparent in the humanly-accessible portions of the conduit system.

Hypogenic karst aquifers with focused recharge may contain the same variety of sediments at their upgradient, unconfined ends as epigenic aquifers. Most of this material is deposited in the conduits prior to reaching the downgradient end, or dissolved and discharged from the aquifer. Diffusely recharged hypogenic aquifers receive few allochthonous clastic sediments, but unless diagnostic allochthonous trace minerals are transported through the system it may be impossible to distinguish focused from diffuse recharge at the aquifer's downgradient end. Analyses of sediment at the downgradient end of hypogenic aquifers may suggest a predominantly autochthonous origin (e.g. Veni \& Heizler 2009), which could be misleading without detailed knowledge of the recharge area and type.

\section{CONDUIT AND AQUIFER EVOLUTION}

Changes in sediment transport and storage, and hence carbon transport and storage, occur over time as karst conduits and aquifers evolve. Most fundamentally, the capacity for sediment storage increases as conduits enlarge. Even when short-term measurements suggest a mass balance in sediment deposition and erosion, storage capacity continues to increase over geologic time as conduits increase in size. Paragenetically formed conduits are excellent examples where sediment accumulates to armor the floor and focus conduit dissolution and enlargement upward.

Natural declines in base level diversify the means and locations for sediment deposition in conduits in four basic stages as illustrated in Fig. 1:

Stage 1. All water and sediment flow occurs through phreatic conduits along a roughly single zone of elevation.

Stage 2. As base level and the karst water table decline, the conduits are either incised to lower elevations and/or lower-elevation conduits form to carry the phreatic flow. The Stage 1 level conduits, as either high-level ledges or as distinct conduits, transmit and store sediments from vadose water as well as from flood-stage rises in the water table. Vadose speleothems may begin to

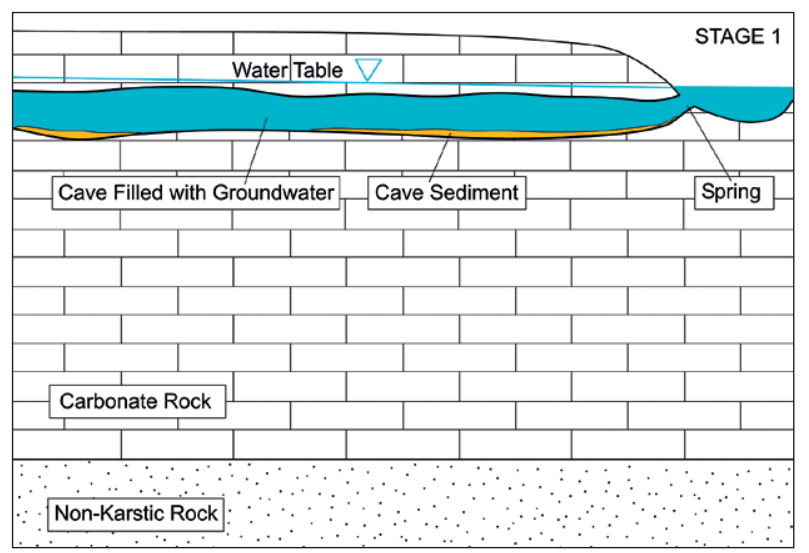

form; speleothems on sediments reduce the sediments' susceptibility to erosion. Phreatic rises from flooding into the Stage 1 levels will deposit sediments and transport sediments downgradient through these now episodically active routes. Many Stage 1 conduits may fill completely with sediment as groundwater flow patterns shift.

Stage 3. Base level and the water table continue to decline, either deepening the existing conduits further and/or creating another level of conduits at an even lower elevation. The processes described for Stage 2 now apply to the two lowest levels. The Stage 1 level now continues to vadosely transmit and store sediment but not phreatic flood flows. In many cases, this level has decreasing hydrologic activity as more direct vertical routes to the water table form and bypass older, more horizontal conduits. Consequently, sediment deposition typically exceeds erosion in the Stage 1 level, especially sediment high in organic carbon brought in by animals and fallin/slide-in from cave entrances and sinkholes. Sedimentoccluded conduits in the Stage 1 level become common.

Stage 4. Base level declines and aquifer conditions change to the point where a water table is no longer sustainable. Flows decrease and are typically episodic, minor, and focused along a few active routes. More sedi-

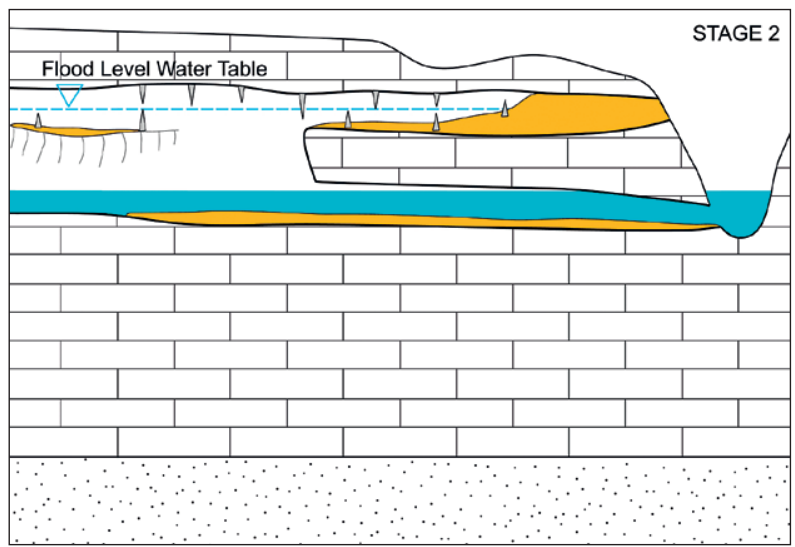



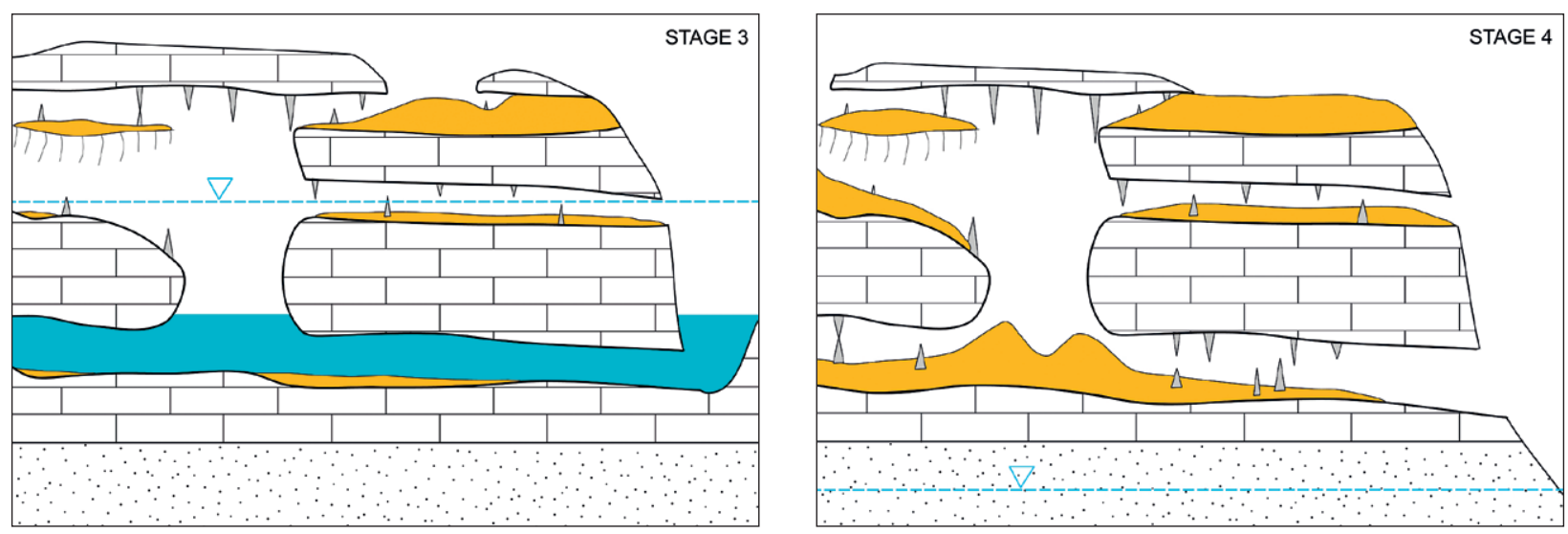

Fig. 1: Conceptual four-stage model of karst aquifer evolution illustrating increases in sediment storage capacity and depositional patterns as related to conduit development and groundwater flow conditions.

ment is deposited than removed through most of the conduit system, with extensive sections of the system potentially filled completely. While primarily a depositional stage, the rate of deposition is relatively slow due to the minor and episodic transport mechanisms of available water, wind, and biota. The sediment is primarily stored in the conduits until the aquifer is hydrologically reactivated by rises in base level or released by denudation of the karst landscape. Mihevc et al. (1998) describe examples of sediment-filled caves exposed by landscape denudation.
This four-stage model is deliberately kept simple for conceptual understanding of how conduit evolution affects sediment/carbon transport and storage. Local variations in geology and hydrology will accentuate or diminish various features associated with each stage. They are illustrated in Fig. 1 under epigenic conditions, but similar changes occur in hypogenic aquifers. As water levels decline in hypogenic karst aquifers, comparable stages take place as total storage capacity increases, flow routes are modified, and in sediment and calcite depositional patterns.

\section{QUANTIFYING SEDIMENT AND CARBON STORAGE}

Critical questions for this paper are how much sediment is stored in karst conduits and what percentage is composed of organic carbon? With the current high level of interest in global carbon balance and searches for carbon sinks to sequester carbon from the atmosphere, only organic carbon plays a notable role in karstic conduit sediments. Karst conduit development and landscape denudation release tremendous volumes of inorganic carbon over geologic time. Groves and Meiman (2001) measured inorganic carbon discharging from the Mammoth Cave System's Logsdon River $25-\mathrm{km}^{2}$ drainage basin at an annual rate of $7.8 \times 10^{3}\left( \pm 1.9 \times 10^{3}\right) \mathrm{kg} \mathrm{ha}^{-1}$. Only $1 \%$ of that total entered the aquifer with recharging water, demonstrating that most is being actively dissolved from the cave walls and/or stored sediment. Only a small amount of this inorganic carbon is recaptured in the karst environment as speleothems in conduits and travertine and tufa at springs. However, while it is so much volumetrically greater than organic carbon, inorganic carbon in karst is of less importance relative to climate change because it is naturally sequestered in karst aquifers at geologic time scales while organic carbon is produced biologically and released for storage into karst aquifers at far more rapid rates.

Herman et al. (2012) provide a detailed overview of sediment transport studies in karst aquifers and offer an insightful analysis of the role of fluid hydrodynanics. Unfortunately, they do not distinguish between organic and inorganic carbon in the sediments. In fact, few data are available to accurately quantify the amount of organic carbon stored in karst conduit sediments. Most early studies of sediment deposits describe organic components qualitatively as "thin beds," "bones," and/or "black staining" visible in profiles, but do not quantify their volumes (e.g. Davies \& Chao 1959; Bramwell 1964). Most published analytical studies of conduit sediments have focused on the mineralogy and either do not analyze for organic carbon or do not report such results (e.g. Gospodarić 1974). Several recent reports examine total and dissolved organic carbon in karst groundwater as tracers and indicators of contamination (e.g. Batiot et al. 2003). 
However, there are a few studies that quantify the volume of organic carbon. For example, Herman et al. (2007) investigated suspended sediment from three karst springs where carbon was found only in trace concentrations. Simon et al. (2007) provide a conceptual model for the flow organic carbon through karst aquifers. Studying two caves in temperate climates, one in Europe and the other in North America, they determined that most organic carbon in karst aquifers is dissolved and enters at mean respective rates of 4.36 and $7.67 \mathrm{mg} \mathrm{C} \mathrm{L}^{-1}$ for sinking streams and 0.70 and $1.1 \mathrm{C} \mathrm{L}^{-1}$ for epikarstic drips. These studies and the literature in general suggest that while karstic sediments commonly contain carbonate rock fragments and minerals, organic carbon is less dense and decomposes far more rapidly than inorganic carbon dissolves, and thus is removed and released into the global environment at far more rapid rates.

The modern interest in sediment storage stems from the desire to understand total sediment and carbon stored in karstic conduits and its potential role in the global carbon budget. Unfortunately, an accurate estimate is impossible given the paucity of data and wide margins of error with the available information. In anticipation of better data, and as a guide to which data are critical to obtain, the following equations are proposed for quantifying the volumes:

$$
\mathrm{Gcs}=\mathrm{Ak} \times \mathrm{Dk} \times \mathrm{Vc} \times \mathrm{Sv}
$$

where:

Gcs $=$ global conduit sediment volume

$\mathrm{Ak}=$ global karst area

$\mathrm{Dk}=$ average depth of karstification

$\mathrm{Vc}=$ average percent of conduit volume

$\mathrm{Sv}=$ average percent of conduit volume filled with sediment

and

$$
\text { Goc }=\text { Gcs } \times \text { Co }
$$

where:

Goc $=$ global organic carbon in conduit storage

$\mathrm{Co}=$ average percent of organic carbon in conduits

Despite the few available data, the equations are used below to roughly estimate global sediment and carbon stored in karst aquifers.

Ak equals $1.7 \times 10^{7} \mathrm{~km}^{2}$ based on Hollingsworth's (2009) mapping of global carbonate and evaporite karst areas. This should be considered a minimum figure. Hollingsworth recognizes significant evaporite karst areas that could not be included in her study. While she did map pseudokarst areas, they are not considered here because their caves are not known to accumulate significant sediment volumes and their distribution of caves remains both poorly understood and unquantified. Lastly, Hollingsworth's totals reflect only karst outcrops and do not account for significant karstification of rocks overlain by non-karstic units.

Dk is estimated as $0.2 \mathrm{~km}$ as a global average. To date there has been no measured average global thickness of carbonate and evaporite units. The United Nations (2011) reports on the mean thickness of various limestone and dolomite units in Europe as ranging from 150-600 m. While some karstified units are much thinner and thicker, $200 \mathrm{~m}$ is suggested as a probable conservative average, not just for bedrock thickness but also as a probably conservative estimate of the thickness of the zone of most significant karstification within those units.

Vc is set at $1.33 \%$. As previously mentioned, Worthington et al. (2000) studied four distinct types of unconfined karst aquifers and found conduit porosity ranged from $0.05-2.8 \%$, or an average of $1.33 \%$. Given the broad range of hydrologic conditions those aquifers represent, their average is used as a possibly conservative estimate of global mean potential conduit storage; a qualitative review of the world's karst outcrops suggests that most are similar to the aquifers with higher conduit porosities.

Sv is the least understood value. While conduits are known to span the range of containing effectively no sediment to being totally occluded, most cave sediment studies and observations are made with little or no knowledge of how much of the cave is actually filled. For this study, Sv is proposed as 50\%. This may instinctively seem too high a proportion of sediment fill, but that instinct is almost certainly biased from predominantly observing caves that have relatively little fill and are thus accessible. Casual observation of road cuts and quarries in karstified rock around the world suggest that sediment filled conduits are generally as common as open conduits, if not more so.

Calculating the above values with equation 1 , the global volume of sediments stored in conduits is estimated roughly as $2.2 \times 10^{4} \mathrm{~km}^{3}$. This figure is potentially very conservative based on conservative estimation of all of the parameters, but this is not assured considering the uncertainty of the data's precision. Taking this a step further, Co is grossly approximated as an average of $1 \%$ of the volume of global conduit sediment based on the discussion earlier in this section. Therefore, following equation 2 , the estimated total global volume of organic carbon stored as sediments in karst conduits is $2.2 \times 10^{2} \mathrm{~km}^{3}$. 
How does this potential volume compare to carbon in the global atmosphere? The World Meteorological Organization (2011) estimated that $3.8 \times 10^{9}$ metric tons of carbon as carbon dioxide were released into the atmosphere since the onset of the Industrial Revolution in 1750 through 2010. In gas form, as a fraction of carbon dioxide, that totals $6.5 \times 10^{3} \mathrm{~km}^{3}$ of carbon. However, organic carbon sediment stored in karst conduits is concentrated in solid form. The density of carbon in such sediments varies and has not been quantified. However, carbon as graphite has a maximum density probably more than an order of magnitude greater than the density of typical solid organic carbon in cave sediments. Therefore, the volume of organic carbon released into the atmosphere since 1750 is probably approximately equivalent to the volume of organic carbon estimated in the previous paragraph as stored in karst.

\section{PALEOKARST: CARBON SOURCE AND SINK}

Much of this paper has focused on the movement and often short-term storage of sediment through karst aquifers. However, once hydrological processes become inactive and/or the area buried under other deposited rocks, the sediment could be stored for long periods of geologic time in paleokarst. Perhaps the oldest example is in the Western Transvaal of South Africa with the age of karstification dating to $2.2 \mathrm{~Gy}$ (Martini, 1981).

Paleokarst areas occur throughout the world. They are included in this paper's discussion because they are well recognized sources of carbon, much of which is being burned as fuel oil and gas, which are widely considered among the primary factors for climate change as the carbon accumulates in the atmosphere. The reason for addressing them here is to provide a rough framework for the volume of carbon they hold in long-term geologic storage as a contrast to the relatively short-term geologic storage described in the preceding sections.

Many of the world's most productive petroleum reservoirs are paleokarst. Notable examples include the Cretaceous Mishrif Formation in the Persian Gulf region (Farzadi \& Hesthammer 2007) and the Ordovician Ellenburger Limestone (Kerans, 1989) and Permian San Andres Dolomite (Craig, 1988) in the Permian Basin of west Texas, USA. However, published global values on hydrocarbons stored in paleokarst seem rare. Schlumberger (2007) reports that carbonate rocks respectively store $60 \%$ and $40 \%$ of the global oil and gas reserves; they further report that $70 \%$ and $90 \%$ of respective Middle East oil and natural gas reserves are held within car- bonate reservoirs but do not report the actual volumes. Data on hydrocarbon production are more available. As an example, the Permian Basin is one of the world's longest major oil-producing regions and since production began in 1921 through the end of 2012, about 29 billion barrels of oil $\left(4.61 \mathrm{~km}^{3}\right)$ have been recovered (Railroad Commission of Texas, 2012), with most yielded from paleokarst. This production figure for this reservoir alone is more than an order of magnitude greater than the total organic carbon stored in modern karst as calculated in the previous section.

A focused and in-depth study is needed to precisely estimate the volume of organic carbon stored in paleokarst, but what purpose would such research serve? Theoretically, much of the volume of oil and natural gas that is removed from paleokarst reservoirs could be replaced by concentrated carbon dioxide for sequestration. Data on the global volume of paleokarst hydrocarbon storage could be used to compare their potential carbon sequestration storage potential relative to other reservoirs. Oil and gas production data from known paleokarst reservoirs, such as the Permian Basin, suggest that the high porosity and permeability of paleokarst, as compared to many fracture and porous media systems, may allow for much faster injection and greater storage capacity per well or unit area. While this hypothesis remains to be tested, unlike the mostly short-term carbon storage in modern, hydrologically active karst systems, sequestration in deeply buried paleokarst would be effectively permanent relative to human history.

\section{CONCLUSIONS}

Sediment is a well recognized feature that occupies and fills many karst conduits, but its study is not as common as its appearance. This paper conceptually evaluates sediment occurrence in karst aquifers and finds it a transient 
material with well over $90 \%$ moved through the aquifer over time. The remaining percentage is stored in conduits for long periods, especially as the aquifer evolves and becomes hydrologically inactive, until the aquifer regains sufficient groundwater flow to erode the sediments or until the karstic bedrock and its conduits are removed by landscape denudation.

Maze and multilevel caves have the capacity to store greater volumes of sediment than most other cave types. Equations are proposed, using the area of mapped global karstic outcrops, mean thickness of karstic units, average conduit volume within karst aquifers, estimated fraction of that volume, and its estimate percentage of organic carbon to set a lower limit on the total global conduit sediment at $2.2 \times 10^{4} \mathrm{~km}^{3}$ and its total organic carbon content as $2.2 \times 10^{2} \mathrm{~km}^{3}$. This volume of organic carbon is similar to the volume released into the atmosphere since the onset of the Industrial Revolution in 1750. Sediment and carbon volumes were not estimated for paleokarst petroleum reservoirs, but the rate and volume they release oil suggests they may prove excellent reservoirs to efficiently and essentially permanently sequester large volumes of atmospheric carbon dioxide.

\section{ACKNOWLEDGEMENTS}

The paper was prepared for the Carbon and Boundaries in Karst Conference co-organized by the Karst Waters Institute and the National Cave and Karst Research Institute. I appreciate their proposing that thought-provoking subject, which prompted this paper. Discussions with and information provided by Drs. Derek Ford and William White during and after the conference proved helpful. I especially thank Dr. E. Calvin Alexander Jr. for his careful review and insightful comments on the manuscript.

\section{REFERENCES}

Batiot, C., Emblanch, C. \& B. Blavou, 2003: Total Organic Carbon (TOC) and magnesium $(\mathrm{Mg} 2+)$ : two complementary tracers of residence time in karstic systems.- Comptes Rendus Geoscience, 335, 2, 205-214.

Bosch, R.F. \& W.B. White, 2004: Lithofacies and transport of clastic sediments in karstic aquifers.- In: Sasowsky, I.D. \& J. Mylroie (eds.) Studies of Cave Sediments - Physical and Chemical Records of Paleoclimate, Klewer Academic/Plenum Publishers, pp. 1-22, New York.

Bottrell, S., Hardwick, P. \& J. Gunn, 1999: Sediment dynamics in the Castleton Karst, Derbyshire, United Kingdom.- Earth Surface Processes and Landforms, 24, 745-759.

Bramwell, D., 1964: The excavations at Elder Bush Cave, Wetton, Staffordshire.- North Staffordshire Journal of Field Studies, 4, 46-60.

Collier, C.R. \& R.F. Flint, 1964: Fluvial Sedimentation in Mammoth Cave, Kentucky. US Geological Survey Professional Paper 475-D, 141-143.
Craig, D.H., 1988: Caves and other features of Permian karst in San Andres Dolomite, Yates Field reservoir, west Texas.- In: James, N.P. \& P.W. Choquette (eds.) Paleokarst, Springer-Verlag, pp. 342-363, New York.

Davies, W.F. \& E.C.T. Chao, 1959: Report on the Sediments in Mammoth Cave, Kentucky.- U.S. Geological Survey Administrative Report to the U.S. National Park Service, Washington.

Farzadi, P. \& J. Hesthammer, 2007: Diagnosis of the Upper Cretaceous palaeokarst and turbidite systems from the Iranian Persian Gulf using volume-based multiple seismic attribute analysis and pattern recognition.- Petroleum Geoscience, 13, 227-240.

Ford, T.D., 2001: Sediments in Caves.- BCRA Cave Studies No. 9, Derbyshire.

Gillieson, D., 2004: Sediments: Allochthonous Clastic.In: Gunn, J. (ed.), Encyclopedia of Caves and Karst, Fitzroy Dearborn, pp. 633-634, New York.

Gospodarić, R., 1974: Fluvial sediments in Krizna Jama.Acta Carsologica, 4, 327-366. 
Groves, C. \& J. Meiman, 2001: Inorganic carbon flux and aquifer evolution in the South Central Kentucky Karst.- In: Kuniansky, E.L. (ed.), U.S. Geological Survey Karst Interest Group Proceedings, USGS Water-Resources Investigations Report 01-4011, 13-16 February 2001, St. Petersburg, Florida, pp. 99-105, Washington.

Hendrickson, G.E, 1961: Sources of Water in Styx and Echo Rivers, Mammoth Cave, Kentucky.- US Geol Survey Water Supply Paper, 424, 41-44.

Herman, E.K., Tancredi, J.H., Toran, L. \& W.B. White, 2007: Mineralogy of suspended sediment in three karst springs.- Hydrogeology Journal, 15, 2, $255-266$.

Herman, E.K., Toran, L. \& W.B. White, 2012: Clastic sediment transport and storage in fluviokarst aquifers: an essential component of karst hydrogeology.Carbonates and Evaporites, 27, 3-4, 211-241.

Hollingsworth, E., 2009: Karst regions of the world (KROW)-populating global karst datasets and generating maps to advance the understanding of karst occurrence and protection of karst species and habitats worldwide. Master's thesis, University of Arkansas, pp. 138.

Kerans, C., 1989: Karst-controlled Reservoir heterogeneity and an example from the Ellenburger Group (Lower Ordovician) of West Texas.- Report of Investigations No. 186, University of Texas at Austin Bureau of Economic Geology, Austin.

Martini, J., 1981: Early Proterozoic paleokarst of the Transvaal, South Africa.- In: Beck, B.F. (ed.), Proceedings of the Eighth International Congress of Speleology, volume 1, National Speleological Society, pp. 6-7, Huntsville.

Mihevc, A., Slabe, T. \& S. Šebela, 1998: Denuded caves an inherited element in the karst morphology, the case from Kras.- Acta Carsologica, 27(1). 165-174.

Palmer, A.N., 1991: Origin and morphology of limestone caves.- Geological Society of America Bulletin, 103(1), 1-21.

Railroad Commission of Texas, 2012: Permian Basin information.- [Online] Available from: http://www. rrc.state.tx.us/permianbasin/index.php [Accessed 5 January 2013].

Sasowsky, I.D., 2004: Sediments: Autochthonous Clastic.- In: Gunn, J. (ed.), Encyclopedia of Caves and Karst, Fitzroy Dearborn, pp. 634-635, New York.

Sasowsky, I.D. \& J. Mylroie (eds.), 2004: Studies of Cave Sediments - Physical and Chemical Records of Paleoclimate.- Klewer Academic/Plenum Publishers, pp. 329, New York.
Schlumberger, Inc., 2007: Carbonate reservoirs - Meeting unique challenges to maximize recovery.- Schlumberger, Inc., pp. 16.

Simon, K.S, Pipan, T. \& D.C. Culver, 2007: Journal of Cave and Karst Studies, 69, 2, 279-284.

Springer, G.R., 2005: Clastic sediments in caves.- In: Culver, D.C. \& W.B. White (eds.) Encyclopedia of Caves, Elsevier, pp. 102-108, Burlington.

Toth, V.A., 1998: Spatial and temporal variations in the dissolved organic carbon concentrations in the vadose karst waters of Marengo Cave, Indiana.- Journal of Cave and Karst Studies, 60, 3, 167-171.

United Nations, 2011: Assessment of transboundary rivers, lakes and groundwaters discharging into the Mediterranean Sea.- Economic and Social Council, Economic Commission for Europe, Meeting of the parties to the convention on the protection and use of transboundary watercourses and international lakes, pp. 85.

Van Gundy, J.J. \& W.B. White, 2009: Sediment flushing in Mystic Cave, West Virginia, USA, in response to the 1985 Potomac Valley flood.- International Journal of Speleology, 38, 2, 103-109.

Veni, G., 2005: Passages.- In: Culver, D.C. and White, W.B. (eds.) Encyclopedia of Caves, Elsevier, pp. 436-440, Burlington.

Veni, G. \& L. Heizler, 2009: Hypogenic origin of Robber Baron Cave: implications on the evolution and management of the Edwards Aquifer, central Texas, USA.- In: Stafford, K.W. et al. (eds.) NCKRI Symposium 1, Advances in Hypogene Karst Studies, National Cave and Karst Research Institute, pp. 85-98, Carlsbad.

World Meteorological Organization, 2011: The state of greenhouse gases in the atmosphere based on global observations through 2010.- Greenhouse Gas Bulletin, 7, 1-4.

Worthington, S.R.H., 1984: The paleodrainage of an Appalachian fluviokarst: Friars Hole, West Virginia.Master's thesis, McMaster University, pp. 218.

Worthington, S.R.H., Ford, D.C. \& P.A. Beddows, 2000: Porosity and permeability enhancement in unconfined carbonate aquifers as a result of solution.- In: Klimchouk A.B. et al. (eds.) Speleogenesis: Evolution of Karst Aquifers, National Speleological Society, pp. 463-427, Huntsville. 